\title{
Promoting Constructivist Early Childhood Education in a Post- modernist Era: Challenges for Nigeria
}

\author{
Florence Taiwo Ogunyemi \\ Department of Childhood Education, Faculty of Education, \\ University of Johannesburg, Soweto Campus, South Africa
}

\begin{abstract}
Debates about the nature of postmodernism have continued to influence the conception and delivery of education of children in many societies including Nigeria. One area in which this has become noticeable is the adoption of 'constructivist early childhood education'. Yet it appears many practitioners in a postcolonial society like Nigeria advocate for constructivist principles without clear understanding of the socio-historic context within which they emerged. This paper explores the major elements of postmodernism and their interconnectedness with constructivist early childhood education. Challenges associated with ongoing efforts at promoting constructivism in early childhood development programmes of post-colonial Nigeria are reviewed in reference to three themes: conception of educational institutions, conception of child upbringing, and implementation of early childhood education policies. The paper notes that Nigeria could still pass for a 'modernising' society and can therefore not fully operate at the postmodernist level. This is more so because the rudiments of democratic culture are yet to take roots. In addition, postmodernism has its own inherent contradictions which could make it not fully applicable in a country like Nigeria. The paper therefore concludes that educational principles associated with postmodernism should be promoted with caution in early childhood centres in the country.
\end{abstract}

\section{Introduction}

The phenomenon called 'postmodernism' has greatly influenced human thoughts and practices since the late $20^{\text {th }}$ century. Usher and Edward [1] explain that "there is a postmodern architecture, art, literature, and even a postmodern psychology". More recent reports (Rajshree [2]; Jensen [3]) indicate that the postmodernist era has also caught up with the theory and practice of education. This influence is perhaps most visible in the field of early childhood education which became institutionalised in Western societies with the industrial revolution of $18^{\text {th }}$ century. Innovative trends and perspectives which have become the hallmarks of childhood education programmes like Montessori, Developmental Appropriate Practice, Reggio Emilia, High/Scope and Te Whariki being replicated through various models across the globe are closely linked with postmodernism.

One major construct which runs through the contemporary models of early childhood development is constructivism. Constructivism is a theory of how children develop their own knowledge by building on the experiences they have and engaging with opportunities in their environment Ogunyemi [4]. However, many educational practitioners may have embraced the principles of 'constructivist early childhood education' without a clear understanding of the postmodernist context of its evolution and current advocacy for it Ogunyemi [4]. From an ideological viewpoint, McLaren and Rikowski [5] insist on "a need to clear the decks of such junk theory and debilitating 'political' posturing". To them, "Postmodernism is an obstacle to the formation of open and radical perspectives which challenge inequalities and the deepening of the rule of capital in all areas of social life.". Therefore, for a non-Western society like Nigeria, continuous exploration of the dimensions of postmodernism in early childhood development is imperative, Among other things, such exploration could assist in bringing out local perspectives to the generalised ideas implicit in discourses about early childhood development practices and issues involved in promoting them with reference to the global trends.

In view of the foregoing, this paper addresses four major questions: (1) what is the nature of the postmodernist era?; (2) what are the features of constructivist early childhood education?; (3) what are the issues associated with promoting early childhood education in Nigeria within a postmodernist era?; and (4) what can be done to address the challenges? 


\section{The Postmodernist Era and Education}

It is impossible to give a universally acceptable definition of postmodernism or precisely what constitutes the postmodernist era because of divergent perspectives in the literature. While introducing their book, Postmodernism and Education: Different Voices, Different Worlds, Usher and Edward [1] warn that 'postmodernism' "is not really a 'system' of ideas and concepts in any conventional sense". As they caution, "Rather, it is complex and multiform and resists reductive and simplistic explanation and explication". However, Muhlpachr [6] submits that postmodernism "stands for more or less developed theories of the current conditions of modernization processes and particularly the outcomes of these processes". Even though the interchangeable use of terms like "poststructuralism', 'post-enlightenment' and 'postanalytic' further attests that postmodernist theorists differ widely, they all seem united by their attempt to respond to the challenges of post-industrial and democracy-inspired society of the $21^{\text {st }}$ century. Prominent among these theorists are Michel Foucault (1926-1984), Jean-Francois Lyotard (1924-1998), Jacques Derrida (1930-2004), and Richard Rorty (1931-2007)

According to Barron [7], three major developments in the emergence of the postmodern society are:

First, there was an intellectual paradigm shift influenced by post structuralism, an intellectual movement originating in the humanities. It is a particular way of looking at claims and evidence. Second, there have been enormous technological innovations that have led to (1) new job definitions and (2) the ability to communicate instantly with anyone anywhere. Third, the economic arena is now global rather than local. These intellectual, technological, and economic shifts are evolving exponentially. What is cutting-edge today is out-of-date in 6 months.

In other words, postmodernism heralded the breakdown of mono-authoritative sources of power such as kings, emperors or other forms of dictatorship which had stifled the growth of knowledge especially during the Middle Ages as well as while the British Empire lasted. As the hierarchical and undemocratic (top-down) decision-making process became challenged, "we are bombarded by multi-viewpoints in every arena - political, economic, social (and education)" Barron [7]. By presenting divergent viewpoints, different notions of historical truth and, thus, reality emerge. This produces relativity, uncertainty, and ambiguity. And it is within this context that postmodernists question the role of the school as the sole route to learning and challenge the teacher's traditional claim to authoritative knowledge.

Muhlpachr [6] further explains that postmodernists describ e the postmodern society as one which is permissive by allowing more than traditional societies on such issues as drugs, homosexuality, sex, difference in educational institutions; lucid by paying more attention to games/play and not considering work to have a major value in life (for example, young people stay at work as long as it is entertaining and does not cause troubles because "life is to be enjoyed not worried about") and secularised by promoting a situation in which the majority of activities does not have religious character, and if it does, then not in the sense of traditional Christianity (but rather sects, new religious movements, etc. such as the Pentecostals in Nigeria); indeed, the society is not seen as a complex where the individual is a part (that is, individualistic orientation). The postmodernist society is also seen as post-moral or one in which morality and moral values are perceived more as a luxury; post-heroic where it is not the heroes who educate but transformed heroes (mutants and virtual idols/computers); and involved in buck-passing with the possibility of justifying and vindicating virtually everything. Other features of the postmodern society identified by Muhlpachr include being posteducational or one where education is out-of-date, because it is assumed that life itself is the best teacher; and globalized implying that the existence of every society depends on the ability and the extent of involvement of the worldwide society in dealing with global problems Muhlpachr [6].

The foregoing characterisation of the postmodernist society suggests that there are contradictions in the ideas and practices associated with the phenomenon of postmodernism. For instance, postmodernism prides itself as "antiphilosophical", yet elements of philosophical thought (metaphysics, epistemology and conceptions of human nature, ethics and politics) can be gleaned from the ideas of leading postmodernist theorists Hicks [8]. Hence Hicks suggests that postmodernism could best be described as "an activist strategy against the coalition of reason and power" because postmodernist theories "believe that in the name of reason, truth and reality Western civilization has wrought dominance, oppression, and destruction" Hicks [8]. Again, while postmodernism supports liberalism and its associated individualism, postmodernists are equally seen as identifying and sympathizing with "the groups perceived to be oppressed in the conflicts (arising from human 
resistant to dominance and oppression)", with "a willingness to enter the fray on their (oppressed) behalf" Hicks[8].

The apparent contradictions in the understanding of postmodernism have serious implications for its application in the field of education. Insisting that education has been "resistant to the postmodern message", Usher and Edward [1] submit that:

Educational theory and practice is founded on the discourse of modernity and its selfunderstandings have been forged by that discourse's basic and implicit assumptions. Historically, education can be seen as the vehicle by which modernity's 'grand narratives', the Enlightenment ideals of critical reason, individual freedom, progress and benevolent change, are substantiated and realised. The very rationale of the educational process and the role of the educator is founded on modernity's self-motivated, selfdirecting, rational subject, capable of exercising individual agency. Postmodernism's emphasis on the inscribed subject, the decentred subject constructed by language, discourses, desire and the unconscious, seems to contradict the very purpose of education and the basis of educational activity.

Nevertheless, the postmodernist era may have finally caught up with educational theory, practice and research generally and early childhood education in particular. Indeed, the influence of postmodernism on curriculum has been profound. The postmodern society conceives the curriculum as "emergent, fluid, chaotic, open and pluralistic" Loggerenberg [9]. Postmodernist thinkers attempt to construct new meanings from the chaotic deconstructed pool of knowledge by rejecting the fragmentation of knowledge into discrete and separable building blocks of information which they describe as destroying meaning. They call for the blurring of traditional boundaries in favour of integration, coordination and inter-relatedness of concepts. Slattery in Loggerenberg [9] summarises the core ideas of the postmodernist curriculum thus:

Curriculum ... in the postmodern era emphasizes discourses that promote understanding of the cultural, historical, political, ecological, aesthetic, theological, and autobiographical impact of the curriculum in the human conditions, social structures, and ecosphere rather than the planning, design, implementation, and evaluation of context-free and value-neutral school events and trivial information.
At the centre of this emergent trend is the constructivist early childhood education.

\section{Postmodernism and Constructivist Early Childhood Education}

Every society, whether industrialised or traditional, literate or illiterate, has always had ways of bringing up its young ones right from infancy. In the traditional setting, activities in this respect revolved around the family (nuclear and extended), the foster agents (including religious and community leaders) and the child through discovery learning. This setting has drastically changed with the rise of the formal preschool system in the aftermath of industrial revolution of the $18^{\text {th }}$ century in Europe. Over the years, the process of care, education and development of children before age eight has evolved into an issue of serious global discourse with the search for national strategies and local practices that best guarantee the right environment for all-round development of the young ones Woodhead [10]. This growing global concern for early upbringing of children to enhance their physical, mental, emotional and social development is what has possibly brought early childhood education into the mainstream of postmodernism and constructivism.

DeLashmutt and Braund [11] have clearly brought out the intersection of constructivism, postmodernism and early childhood education by observing that:

A key word to learn when trying to understand postmodern education is constructivism. Constructivism is the main underlying learning theory in postmodern education. The basic idea is that all knowledge is invented or "constructed" in the minds of people. Knowledge is not discovered as modernists would claim. In other words, the ideas teachers teach and students learn do not correspond to "Reality", they are merely human constructions. Knowledge, ideas and language are created by people, not because they are "true", but rather because they are useful.

Thus, constructivism is an educational theory whose popularity is rooted in the postmodernist society. The constructivist argument that children learn best when they are encouraged to construct their own meaning of the experiences to which they are exposed dates back to the times of Socrates, Plato and Aristotle. However, the foundation of contemporary advocacy for constructivism in early childhood education was laid by educational thinkers like Rousseau, Piaget, Vygotsky, Dewey and 
Montessori who were critical of educational provision and processes of the 'modernising' societies of the $18^{\text {th }}, 19$ th and $20^{\text {th }}$ centuries Ogunyemi [4].

Evidence of constructivism and postmodernism in early childhood education is perhaps most evident in curriculum models. b The concept of 'curriculum', among other things, involves "the purposes of education, the content of teaching, teaching approaches with the focus being on the product as well as the process and a programme of evaluation of the outcomes" Hok-chun [13]. Curricular approaches like the High/Scope, the Reggio Emilia and Te Whariki present models of early childhood curriculum with implications for classroom practices. For instance, Ryan and Grieshaber [14] employed postmodern views of knowledge, power, and subjectivity to enact a postmodern early childhood teacher education based on situating knowledge, multiple readings, and engaging with images. Their work underscores the need to expand and improve on the application of constructivism through, for example, the provision of "time and multiple opportunities to grapple with the complexities and implications of differing theoretical frameworks" Ryan and Grieshaber [14]. Drawing from the experience of "one of the largest accredited Montessori schools in the United States serving only the early childhood level" (the West Side Montessori School), Barron [7] concludes:

Today's children are very different from those with whom Maria Montessori worked. Our children are bombarded with visual symbols and jingles - from advertisements on kiosks and billboards to television, videotapes, and storybooks. We are deluding ourselves if we think that young children today are not aware that there is a difference between reality and fantasy. However, their boundaries between these two categories may be vague and confused, which is why we need to include story books in the classrooms.

In a nutshell, the goals, content and strategies outlined for early childhood education programmes define their relevance within the constructivist cum postmodernist paradigm. While conceptualising this paradigm, Boboc and Nordgrem [14] highlighted five postmodernist education principles which could be regarded as providing the foundations for constructivism, these are:

Customising teaching and learning: That is, teaching and learning must focus on individual needs and embrace the context within which teaching and learning take place.
Focusing on creative learning: The emphasis should be on how learners gain knowledge as well as how teachers are able to improve their professional competencies/practices.

Encouraging risk-taking: Learners' learning and the teaching practice must be fully accommodated by the organizational and leadership structure both in the school and the school community.

Learning from the past and owning innovation: The teaching and the school leadership practice must constantly be based on past experiences in the field of education and not borrowed from business.

Engaging in share responsibility and trust: Responsibilities must be shared among the internal school community and the larger community within which the school serve. Also mutual trust must be demonstrated all the time.

\section{Challenges for Nigeria}

Early childhood education in Nigeria has evolved through three major phases: the pre-colonial, the colonial, and the post-colonial. The pre-colonial era was the period before the coming of the Western missionaries and British colonial powers as from the mid- $19^{\text {th }}$ century. During this period, the care and upbringing of the Nigerian child was done absolutely within the traditional setting of the family and community care and development. However, with introduction of formal school system following the establishment of the first primary school in 1842 by the Wesleyan Methodist Missionary in Badagry, an admixture of tradition and modernity became the order of the day. The place of preschool education at this early stage was not clear because children of diverse age-groups were accommodated through the Sunday school arrangements as well as elite-oriented centres at Government Reservation Areas (GRAs) which catered for children of employees working in colonial government establishments and European commercial outposts. The third phase of the evolution began marginally when Nigeria gained political independence from Britain in 1960 but did not take a firm root until the formulation of the country's National Policy on Education (NPE) in 1977 Ogunyemi [4].

The Report of the National Curriculum Conference of 1969, titled A Philosophy for Nigerian Education Adaralegbe [15], which gave rise to the NPE, was the first official document to encourage government support for early childhood education. The Report advises that, "where and when the need is felt, younger children between three and five years old may be enrolled in nursery and kindergarten classes to prepare them for the lower primary classes" Adaralegbe [15]. 
This loose recommendation at the 1969 curriculum conference significantly contributed to the official neglect of preschool education until it became part of the Universal Basic Education (UBE). The 1977 NPE, like its revised editions in 1981 and 1998, recognized and supported the development of preprimary education. However, "this was restricted to children aged 3-6 years who attend (private) nursery schools, which in most cases charge high fees" FME [16]. It was not until the 2004, following the introduction of the Universal Basic Education (UBE) in 1999, that early childhood education started to enjoy some attention as an issue of human right. Consequently, the Nigerian government legislated to compulsorily make direct annual financial allocation towards providing early education to all her young learners under UBE. However, the $6^{\text {th }}$ edition of the NPE recently restricted this provision in public primary schools to children age 4-5 years through a one-year kindergarten education FRN [17].

In Nigeria, teaching at the preschool level is expected to be activity-based and the main method of facilitating learning should be through play. In furtherance of these pedagogical prescriptions, the curriculum of teacher preparation for early childhood educators should be oriented towards activity-focused and play-related learning experiences Ogunyemi [4]. The policy context for these preschool programmes and strategies stresses developing the child into "a sound and effective citizen" FRN [18]. In addition, the policy aims at fully integrating the child into the life of the community with "equal access to educational opportunities" FRN [18]. Thus, it appears obvious that the Nigerian early childhood education programme borrows much from the contemporary paradigms in North America and Europe which are rooted in constructivism and postmodernism.

Consequently, applying constructivism in early childhood education against the background of its history and current advocacy in Nigeria, points to a number of issues that must be handled decisively and diligently. As aptly captured by Muhlpachr [6], "The interpretation of post-modernism and its outcomes for education of the young generation projects itself also into the conception of educational institutions, the conception of upbringing in the family, and reflects itself also in the country policies towards the young generations". The three issues which are discernible from the submission of Muhlphachr certainly apply to the Nigerian experience. These are: the conception of educational institutions, the conception of upbringing in the family, and the country's early childhood education policies.

\section{Conception of educational institutions}

The postmodernist approach stresses the general recognition of plural and multicultural nature of the modern society serves to encourage the accommodation and promotion of the experiences of individual learners in the context of education. Also, the breaking down of 'hierarchical authority' in the process of meaning-making suggests that there will be less inhibition to the child's construction of knowledge. For, as asserted by Barron [7],

The days of the vertical classroom with the teacher at the head are over. The days of teacher education programs with the "expert" conveying the truth are also over. Top-down practices might have worked in the modern world; they simply are not effective for the postmodern world.

In a postmodernist Nigeria, the teacher and learner are expected to work as partners (lateral engagement) to promote the child's learning. For instance, a nursery school child of today who possesses relevant skills in internet surfing may obtain more information on any concept (say, the family) than a school or physical teacher could provide him or her within a 30-minute lesson period. At the mere pressing of the right buttons, the search engine could yield 100,000 or more possible sources of information many of which might not even be known to the teacher. While this in itself may create confusion, postmodernists believe that the child gets better informed when (s)he finally gets out of the confusion. Viewed from this angle, postmodern thought may be supportive of constructivism with the goal of making learners drive their own learning.

However, postmodernists' insistence on lose control of education or extreme permissiveness tends to support anarchism. Education seizes to be a worthwhile activity where 'anything goes'. For instance, if everyone is 'free' to do what they like in an educational institution like the nursery school, there will be no order, and no meaningful learning can take place in a setting of disorderliness. According to the Global Monitoring Report Team [19], "A particularly interesting and consistent research finding is that the relationship between carers and children is the single most important determinant of quality in these early years, over and above availability of play materials or other 'inputs'."

Therefore, for a largely rural Nigeria, where the permissive culture of the urbanised Western societies is unwelcome, 'loose freedom' in schools may generate an educational crisis of unmanageable proportions. Thus, only improved capacity of teachers and caregivers in the emergent philosophical orientation would help in mitigating the inevitable 
clash of values which may result for current promotion of a postmodernist construct like constructivist early childhood education.

In addition, the attempt to elevate technologies, particularly computers and the Internet (virtual idols), over and above the teacher is equally flawed. One way or the other, a physical or surrogate teacher provides the initial training in the use of computer to the learner as the child cannot build something on nothing. In other words, the application of computers in early childhood education centres should be done with circumspection. In the context of constructivist education, Healy [20] counsels that:

With young children it is even more important than with older ones to determine what we want them to learn before choosing the technology to do the job. Purchase equipment because it fits a specified need, not because it's "cute" or novel. In fact, if we define "technology" more broadly as "any tool that extends the senses", such as hand lenses, magnifying bug boxes, string telephones, compasses, thermometers, creative art materials, rulers, and audiotapes, computers become only one of many options for early learning. Moreover, because young children require 30 to 50 minutes of free play or independent exploration to become fully engaged in learning materials, occasional large blocks of time with adult supervision not superficial jabs at software - should be scheduled.

The major implication of this is that computers or other forms of sophisticated technology may, in reality, hinder the child's all-round (physical, cognitive, social, cultural, emotional) development if not wisely applied. For example, many sub-standard nursery schools in Nigeria tend to advertise availability of computers as bait to unsuspecting parents who usually regard this as evidence of 'modernity'. In most of these preschool centres, however, ability to deploy the technology in ways that promote holistic development of early childhood learners may be lacking because of limited capacity for computer use across the nation FRN [18]. So, in the Nigerian context, computers cannot totally replace counting sticks, abacus, sand tray, paper mâche, local toys and such other familiar devices that readily project children's thinking faculties from the informal setting of their homes into the semi-formal arrangement of early childhood education centres Ogunyemi [4].

The likely 'confusion' in postmodernist classrooms in Nigeria is equally better resolved by recourse to the physical teacher lest the process of learning become unproductive or frustrating to the young learner. Otherwise, a fertile ground for the production of "out-of-control" children may be laid. As Reesa Sorin [22] (quoting Levy and Orlans) avers, "out-of-control children are the product of attachment disorder, where failure to develop secure attachments to loving caregivers early in life has developed into 'aggressive, controlling and conduct-disorder behaviours that contribute to the development of an anti-social personality' ". Cases of out-of-control children abound not only in the industrially advanced societies FRN [18], but also in less-industrialised nations including Nigeria Global Monitoring Report Team [19]; Healy [20], Oyeniyi [21]. So, the focus, as advised by constructivist educators, is about recognising the Agentic Child who can co-construct curriculum and knowledge through adult collaboration Ogunyemi [4]. However, it appears that the Nigerian Government is yet unclear about the focus and enforcement of early childhood education policies and programmes especially in the area of teacher development for effective response to the challenges of constructivism and postmodernism. This point is elucidated presently under the review of policies.

\section{Conception of the family}

All the popular models of constructivist early childhood curriculum emphasize the role of parents and the family. As observed by Ogunyemi [4],

The constructivist orientation is used to encourage children to construct understanding of the world through interaction with materials and the environment. The ultimate goal is the development of the whole-child (physically, socially, intellectually and morally); using education to promote social change and social justice. Like Reggio, the importance of the family in the early education of the child is also stressed in the developmentalinteraction approach. Hence, materials for learning include teacher-made and parentmade items as well as child-made ones that relate to the child's own world.

Therefore, parents are major stakeholders in the education of their children. In particular, the mother is the child's first teacher. She initiates communication and trains the child in elementary hygiene, simple courtesy and other forms of social habits in preparation for extended contacts with the outside world. Studies have underscored the critical place of parents in early childhood education Reesa Sorin [22]. "The evidence base currently suggests three family involvement processes aid in creating this match and promoting healthy outcomes: 
parenting, home-school relationships, and responsibility for learning outcome" Reesa Sorin [22]. Parenting involves two basic activities, namely: parent-child relationship and participation in childcentred activities. Home-school relationships demand communication and participation on the part of parents. And the responsibility for learning outcomes requires that parents read at home with their children and as well encourage parent-child conversations. All this should ideally yield child outcomes such as social competence, cognitive development, communication skills literacy development, vocabulary growth, expressive language, comprehension skills, positive engagement with peers, adults, and learning. It is within this context of parental role performance that constructivism is being promoted in early childhood education in Western societies.

The situation in Nigeria is, however, highly challenging. With adult illiteracy put at about 60 percent and over 70 percent of Nigerians earning below US\$2 per day Ogunyemi [4], it becomes a herculean task getting parents to perform the three inter-connected roles- highlighted above. Yet, no meaningful early childhood education can take place without effective partnering with parents. Indeed, "Involving parents as advocates is a particularly effective way to promote sustainable programmes" Adaralegbe [15].

\section{Government policies}

Between the 1977 and 2013, there have been six versions of Nigeria's NPE with each coming up with varying emphasis on the importance of early childhood care and development. For instance, whereas government promised to establish Nursery Education (age 0-5) as adjunct of primary schools and some were actually established on experimental basis FRN [19], this policy was reversed in 2013. Under the new policy the Nigerian Government would only support one-year of Kindergarten Education for children age 5 while the provision of Early Childhood Care, Development and Education (ECCDE) would be taken care of through "community and private efforts...based on set standards" FRN [18]. Viewed against the background of a postmodernist society, it is obvious that government's withdraw from the provision of nursery education (age 0-5) will further expose Nigerian parents to exploitative practices of 'private investors' who are reputed for charging exorbitant fees and proliferation of mushroom early childhood education centres Ogunyemi [29].

More than ten years after the Universal Basic Education (UBE) scheme was launched, it is yet to be clearly established that early childhood education centres have been integrated into the Nigerian primary school system. In the Country Report on Education for EFA 2001, Nigeria set various targets. By 2010, 70 per cent of the National Budget on education was be spent on early childhood care and development programme; by 2015,70 per cent of the children enrolling in primary school would have participated in at least one year of early childhood care and development programme; and by 2015 , enrolment in early childhood programme would increase to 70 per cent. The reality on ground however suggests that these targets were unrealistic. Available statistics indicate that participation in early childhood education in many states is below 10 per cent while over 60 per cent of the facilities are available only in the urban centres where less than 30 per cent of Nigerians reside. The net enrolment rates among children age 4 and 5 have also been put at only about 20 percent Good Planet Foundation [29].

Obstacles to participation are largely connected with the issues of availability and affordability. Over 70 per cent of young children in need of preschool education in Nigeria are from poor homes. They are likely to be discouraged from participation in this foundational education unless government (Federal, State and Local) come to their aid. However, it has been found that over 60 per cent of early childhood education facilities are owned by private owners (mostly religious groups and business entrepreneurs) whose primary interest is in profit-making. This situation must have been worsened the withdrawal of government from the provision of nursery education under the new National Policy on Education FRN [17].

The diminishing presence of the Nigerian government in supporting early education contrasts sharply with what obtains in Western societies and even some less developed countries of the world. For example, the Head Start has remained the foremost federally-funded provider of educational services for children of the poor in the United States of America since 1965.

Apart from providing educational services, "Head Start also provides social, health, and nutritional services to children and their low-income parents" Barnett and Hustedt [30]. In addition, an Early Head Start was introduced in 1994, thereby expanding the program "to serve even younger children (from birth to age 3) and their families" Barnett and Hustedt [30]. South Africa, Ghana, Malawi and Kenya are some of the Third World countries with functioning system of government support for early education. In particular, "South Africa's Primary School Nutrition Programme (PSNP), established in 1994, is designed to improve the health and nutritional status of 
primary school children, improve school attendance and improve the learning capacity of children" The Guardian [31], p.16. However, Nigerian government has, so far, been oscillating within the orbit of rhetoric. A recent editorial opinion vividly sums the trend:

That abject poverty is wreaking havoc in most families is no longer in doubt and families in this predicament, who can hardly afford one meal a day, find it extremely difficult to send their kids to school. This has, for long, been an endemic problem culminating in the rising number of out-ofschool children. Government should indeed move from rhetoric to real action on this very initiative to save Nigeria's future The Guardian [31].

Although the National Policy for Integrated Early Childhood Development in Nigeria acknowledges the need to "Develop a healthy, well nourished adequately stimulated child (who will be) able to achieve its fullest potentials" FME [32]. Issues bordering on policy implementation in respect of social, health and nutritional services are still largely political in Nigeria Ogunyemi [4].

It is perhaps in the area of language policy that government's lack of will is most evident. The need to "develop the orthography of many more Nigerian languages" and "produce textbooks in Nigerian languages" so as to "ensure that the medium of instruction is principally the mother-tongue or the language of the immediate community" FME [32] has been a major feature of the NPE since 1977. However, available evident indicates that well over 70 per cent of early childhood education facilities in the country still adopt English language for instruction FME [17]. The situation is compounded by the widely reported fact that "most parents would like their children to speak English language as soon as they start ECC/Pre-primary schools." Maduewesi [33]. In fact, less than five per cent of the respondentteachers from a recent study declared that they encouraged their students to use mother-tongue in early childhood education centres Ogunyemi [28]. However, constructivism is meaningful when its application is grounded in the children's culture as conveyed through the language of their community.

The seeming helplessness of governments at the federal, state and council levels to enforce the language policy therefore constitutes a major threat to the realisation of constructivism in Nigerian early childhood education.

\section{Conclusion}

This paper has reviewed the challenges of promoting the constructivist paradigm for early childhood education in contemporary Nigeria. Postmodernism is a product of diverse efforts to explain human existence in the post-industrial society. The evidence suggests that the idea of constructivist early childhood education became popular within the broad context of postmodernism.

Nigeria can best be described as a 'modernising society' with patches of postmodernism. The country is still striving to get industrialised and deepen its tenets of democracy - two critical features of a postmodernist society. Traditional approaches to early childhood education are still palpable, just as the popularity of westernized preschools is on the increase. For this reason, there is need for conscious efforts to factor local realities (poverty, joblessness, dominant rural population) into educational policy formulation and implementation within the particular context of constructivism and postmodernism.

Three critical areas need attention as Nigeria gravitates towards implementing constructivist early children educational programme and policies. One, the country may need to revisit the conceptualisation of its framework for provision of pro-poor early childhood education facilities as proposed (but poorly implemented) under the 2004 version of the National Policy on Education. Two, there is the need to formulate clear-cut guidelines for parent education to bring about an effective partnership between the home and the preschool institutions. Three, enforcement of guidelines on early childhood development and care is sine qua non to successful programming in a 'modernising' clime like Nigeria'

\section{References}

[1] R. Usher, \& R. Edwards, (1994). Postmodernism and education: Different voices, different worlds. London: Routledge.

[2] Rajshree, (2012). Themes of Postmodern Education International Journal of Scientific and Research Publications, (2) 12, 2012 1ISSN 2250-3153

[3] Jensen, A. S., (2013). Didaktik on Postmodernism's Doorstep: A Critical Approach to Teaching and Researching Literacy in Early Childhood Education and Care, Dissertation for the degree of Philosophieae Doctor (Ph.D) Emdrup, Aarhus University, February.

[4] F. T. Ogunyemi, (2012): Epistemological relevance of constructivism in early childhood education in Nigeria. Unpublished PhD thesis, Department of Teacher Education, University of Ibadan, Ibadan. 
[5] P. McLaren, \& G.Rikowski, (1999). Postmodernism in educational theory. In Hill, D., McLaren, P., Cole, M. \& Rikowski, G.( Eds) Postmodernism in educational theory, education and politics of human resistance. London. The Tufnell press.

[6] P. Muhlpachr, (2008). Social determinants of education in postmodern society. Santslka: Filologija, Edukologija, 16.4 , pp61 67 http://repozytorium.amu.edu.pl/jspui/bitstream/10593/1242 2/1/muhpachr.pdf (26 January 2015)

[7] Marlene. Barron, (2002). Maria Montessori and the Postmodern World. Montessori Life; Summer, 14 (3), p25M.

[8] Stephen R. C. Hicks, (2004). Explaining Postmodernism: Skepticism and Socialism from Rousseau to Foucault (ISBN 1-59247-646-5)

[9] A. Van Loggerenberg, (2000). Implementing a problem-based learning model in the training of teachers for an outcomes-based technology curriculum. PhD Dissertation. University of Pretoria: Pretoria.

[10] M. Woodhead, (2006). Changing Perspectives on Early Childhood: Theory, Research and Policy, Background paper prepared for the Education for All Global Monitoring Report 2007, Strong foundations: early childhood care and education, Paris: UNESCO.

[11] G. DeLashmutt, \& R. Braund, (n.d). Postmodernism and/MINISTRIES/crossroads/doteduc.html you: Education. Retrieved May, 2015),www.xenos.org//MINISTRIES/crossroads/doteduc.h tml (12 May, 2015).

[12] A. D. Koo Hok-chun, (2002). Quality education through a post-modern curriculum. Hong Kong Teacher's Centre Journal, 1, 56-73

[13] Sharon Ryan, \& Susan J. Grieshaber, (Eds.) (2005). Practical Transformations and Transformational Practices: Globalization, Postmodernism, and Early Childhood Education: Advances in Early Education and Day Care. Advances in Early Education and Day Care, 14. Elsevier JAI, The Netherlands, Amsterdam.

[14] Boboc, R.D. Nordgren. (2014) Modern and PostModern Teacher Education: Revealing Contrasts in Basic Educational Beliefs and Practice Journal of Research in Innovative Teaching 7 (1), 14-26

[15] Adaralegbe, (1972). A philosophy for Nigerian education. Ibadan: Heinemann Educational Books.

[16] Federal Ministry of Education. (2005). Nigeria Education Sector Diagnosis: A Framework for Reengineering the Education Sector. A Condensed Version. Nigeria.
[17] Federal Republic of Nigeria (2013). National Policy on Education, Revised. National Education Research and Development Council, Yaba, Lagos.

[18] Federal Republic of Nigeria (2004). National Policy on education 4th Edition. National Education Research and Development Council, Yaba, Lagos.

[19] Global Monitoring Report Team (2006).Strong Policies to Benefit Young Children, Journal of Education for International Development 2:3. http://www.equip123.net/jeid/articles/4/StrongPoliciestoBe nefitYoungChildren.pdf.

[20] J. Healy, (2008). Cybertots: Technology and the preschool child. In A. Pelo (Ed.), Rethinking early childhood education (pp.75-83). Milwaukee: Rethinking Schools. 76-

[21] O. Oyeniyi, (2008) A survey on Implementation of the National Computer Education Curriculum in Selected Primary Schools in Kubwa, Federal Capital Territory, Abuja. Nigerian Journal of Curriculum Studies, 13 (2) pp $44-56$

[22] Reesa Sorin, (2005) Changing images of childhood: reconceptualising early childhood practice. International Journal of Transitions in Childhood, (1). pp. 12-21.

[23] J. Clarke, (2004c). Childhood and Juvenile Delinquency. In: D. Wyse (ED.), Childhood Studies: An Introduction, (pp. 83-88). Oxford: Blackwell Publishing.

[24] J. N. Okorodudu, (2010). Influence of parenting styles on adolescent delinquency in Delta Central Senatorial District, Edo Journal of Counselling, (3) 1, pp 58-86

[25] Bernard Akinlabi Falana and Festus Olatunji Bada, (2010). The Influence of Sex on Inclination to Crime among Secondary School Students. The Social Sciences, 5: 373-375.

[26] K. B. Sanni, N.A. Udoh, A.A Okediji, F. N. Modo, and L.N Eze, (2010). Family Types and Juvenile Delinquency Issues among Secondary School students in Akwa Ibom State, Nigeria Counselling Implications IN: Journal of Social Sciences 23(1): 21-28.

[27] R. Giallo, K .Treyvaud, J. Matthews, and M .Kienhuis (2010). 'Making the transition to primary school: An evaluation of a transition program for parents', Australian Journal of Educational and Developmental Psychology, (10), pp. 1-17.

[28] F. T. Ogunyemi, (2013). "Mushroom private nursery/primary schools: The bane of qualitative early childhood education." Contemporary Issues In Nigeria Education. Ed. P.K. Ojedele, M.O. Arikewuyo and A.C. Njoku. Ondo: Nigeria, National Institute for Educational Planning and Administration. 
[29] Good Planet Foundation (2013). Accelerating progress to 2015, Nigeria. A Report Series to the UN Special Envoy for Global Education, Working Paper, April 2013.

[30] W.S. Barnett, \& J. T. Hustedt, (2005). Head Start's lasting benefits. Infants \& Young Children, 18, (1), 16-24.

[31] The Guardian (Lagos), (September 25, 2015). On the school feeding programme. Editorial. http://www.ngrguardiannews.com/2015/09/on-the-schoolfeeding-programme/

[32] Federal Ministry of Education. (2007). National policy for integrated early childhood development in Nigeria. Abuja: Federal Ministry of Education.

[33] Maduewesi, E. J. (2005). Benchmarks and global trends in education. Benin City: Dasylva Influence Enterprises. 